\title{
ANALISIS KEPUASAN KONSUMEN PADA PRODUK OLAHAN RENGGINANG (STUDI PADA UD. SARWANI DESA GELUNG KECACAMATAN PANARUKAN KABUPATEN SITUBONDO)
}

\author{
Muhammad Hendra Priyono ${ }^{1)}$, Gema Iftitah Aunegrah Yekti ${ }^{2 *}$ \\ 1) Mahasiswa Fakultas Pertanian Universitas Abdurachman Saleh Situbondo \\ 2) Staf Pengajar Fakultas Pertanian Universitas Abdurachman Saleh Situbondo \\ *Email: gema_iftitah@unars.ac.id
}

\begin{abstract}
Abstrak
Kepuasan konsumen merupakan faktor yang sangat penting bagi keberadaan, kelangsungan, dan perkembangan perusahaan. Saat ini banyak perusahaan yang semakin memahami arti penting dari kepuasan konsumen, dan menjalankan strategi guna memberikan kepuasan bagi konsumennya. Tujuan penelitian ini adalah untuk mengetahui tingkat kepuasan konsumen dan untuk menguji pengaruh kualitas produk, harga, service quality, emotional factor, dan biaya terhadap kepuasan konsumen pada produk olahan rengginang UD. Sarwani. Teknik pengambilan sampel menggunakan teknik probability sampling dengan metode teknik aksidental sehingga diperoleh sampel penelitian sebanyak 50 responden. Berdasarkan hasil penelitian bahwa kualitas produk, harga, service quality, emotional factor, dan biaya berpengaruh terhadap kepuasan konsumen pada produk olahan rengginang UD. Sarwani di Kabupaten Situbondo. Variabel yang dominan yaitu harga. pengujian statistik dengan menggunakan metode uji $\mathrm{F}$, diketahui nilai $\mathrm{F}_{\text {hitung }} 11,474$ $>F_{\text {tabel }} 2,430$ dengan tingkat signifikan yang diperoleh $0,000<0,05$, maka dapat disimpulkan bahwa terdapat pengaruh kepuasan konsumen pada produk olahan rengginang UD. Sarwani di Desa Gelung Kecamatan Panarukan Kabupaten Situbondo.
\end{abstract}

Kata kunci: Kepuasan Konsumen, Rengginang, Produk Olahan

\begin{abstract}
Customer satisfaction is a very important factor for the existence, continuity and development of a company. Today many companies are increasingly understanding the importance of customer satisfaction, and implementing strategies to provide satisfaction to their customers. The purpose of this study was to determine the level of customer satisfaction and to examine the effect of product quality, price, service quality, emotional factors, and costs on customer satisfaction in UD Rengginang processed products. Sarwani .. The sampling technique used probability sampling techniques with accidental technique methods in order to obtain a research sample of 50 respondents. Based on the results of the research that product quality, price, service quality, emotional factors, and costs have an effect on consumer satisfaction with UD Rengginang processed products. Sarwani in Situbondo Regency. The dominant variable is price. statistical testing using the F test method, it is known that the value of Fcount is 11.474> Ftable 2.430 with a significant level of $0.000<0.05$, it can be concluded that there is an effect of consumer satisfaction on the processed product of rengginang UD. Sarwani in Gelung Village, Panarukan District, Situbondo Regency.
\end{abstract}

Keywords: Customer Satisfaction, Rengginang, Processed Products

\section{PENDAHULUAN}

Rachman dan Sumedi (2002), mengemukakan permasalahan umum dalam pengembangan agroindustri, yaitu sifat produk pertanian yang mudah rusak sehingga diperlukan teknologi pengemasan dan sarana transportasi yang mampu mengatasi masalah tersebut, sebagian besar produk pertanian bersifat musiman dan sangat dipengaruhi kondisi iklim sehingga aspek kontinuitas produk agroindustri tidak terjamin, kualitas produksi pertanian dan industri yang dihasilkan pada umumnya masih rendah 
sehingga mengalami kesulitan dalam persaingan pasar, dan sebagian besar industri berskala kecil masih menggunakan teknologi rendah. Karakteristik tersebut sesuai dengan produk pertanian yang mudah rusak sehingga untuk mengatasinya diperlukan pengolahan.

Kepuasan konsumen merupakan faktor yang sangat penting bagi keberadaan, kelangsungan, dan perkembangan perusahaan. Saat ini banyak perusahaan yang semakin memahami arti penting dari kepuasan konsumen, dan menjalankan strategi guna memberikan kepuasan bagi konsumennya.

Seiring semakin konsumtif dan bervariasi perilaku konsumen di Situbondo terhadap produk rengginang dan didukung dengan jumlah penduduk yang besar maka tidak sedikit para pengusaha tertarik menjalankan bisnis atau usaha agroindustri rengginang. Perkembangan dunia usaha saat ini semakin hari semakin berkembang. Setiap perusahaan dituntut untuk memenuhi dan mengimbangi perubahan yang terjadi. Persaingan dimana perusahaan mengedepankan keunggalan masing-masing dan berusaha untuk memuaskan konsumen, salah satunya yaitu perusahaan yang bergerak di bidang agroindustri

Agroindustri rengginang di Situbondo yang ada saat ini berada di daerah Utara tepatnya di Desa Gelung Kecamatan Panarukan Kabupaten Situbondo. Sebagian besar masyarakat disana memiliki usaha makanan jajanan kerupuk rengginang yang sebagai penghasil ekonomi keluarga. Lokasinya yang dekat dengan tempat wisata dan strategis,dapat menjadikan suatu peluang usaha untuk mendirikan usaha tersebut guna mengenalkan jajanan kering khas di tempat tersebut. Menarik minat konsumen dan wisatawan yang setiap kali mampir untuk mencicipi jajajan kering kerupuk rengginang sebagai oleh oleh jajanan kota situbondo.

Memasuki era otonomi daerah, pengembangan agroindustri menjadi pilihan UD. Sarwani dan pengusaha agroindustri rumahan yang lainnya seperti UD. Winda, UD. Taufik untuk mendorong peningkatan pendapatan keluarga. Dengan tersedianya sumber daya lokal yang berupa produksi ketan yang melimpah, maka industri pengolahan ketan menjadi produk olahan rengginang yang sangat beragam mampu bersaing dan berkembang dengan baik. Diharapkan mampu menjadi produk makanan khas dari Kabupaten Situbondo. Semakin banyaknya agroindustri rumahan yang berkembang di Desa Gelung, maka produksi olahan rengginang sangat bervariasi. Baik dari segi Rasa, kualitas produk, dan harga pun berbeda. Sehingga mampu menarik minat kosumen dalam membeli produk olahan rengginang yang ditawarkan.

Berdasarkan uraian latar belakang masalah yang telah dikemukakan di atas, maka rumusan masalahnya sebagai berikut: Bagaimana tingkat kepuasan konsumen rengginang terhadap produk rengginang UD. Sarwani? Apakah faktor kualitas produk, harga, service quality, emotional factor dan biaya berpengaruh terhadap kepuasan konsumen?

\section{METODE PENELITIAN}

Penelitian ini di lakukan secara sengaja (purposive Method) yang dilaksanakan di UD. Sarwani yang bertempat di Desa Gelung Kecamatan Panarukan Kabupaten Situbondo, pada bulan April 2019 sampai selesai, agar hasil dari penelitian ini sesuai dengan tujuan yang ingin di capai oleh peneliti. Pemilihan lokasi penelitian di lakukan setelah dilakukan survei langsung ke tempat agroindustri rengginang UD. Sarwani. Penetapan lokasi didasarkan atas pertimbangan bahwa agroindustri ini di nilai cukup layak untuk dijadikan tempat penelitian dilihat dari produksinya yang banyak. UD. Sarwani memproduksi rengginang menggunakan bahan utama beras ketan dengan lima variasi rasa yaitu rasa bawang, rasa cumi, rasa terasi, rasa terasi pedas, dan rasa seledri.

Populasi yang diambil dalam penelitian ini adalah konsumen yang tidak diketahui jumlahnya. Karena konsumen tidak diketahui jumlahnya, maka teknik sampling yang digunakan yaitu non Probability sampling dengan teknik aksidental. Non Probability 
Sampling adalah teknik pengambilan sampel yang tidak memberi peluang atau kesempatan sama bagi setiap unsur atau anggota populasi untuk dipilih menjadi sampel. Sampling aksidental adalah teknik penentuan sampel berdasarkan kebetulan, yaitu siapa saja yang secara kebetulan bertemu dengan peneliti dapat digunakan sebagai sampel, bila dipandang orang yang kebetulan ditemui itu cocok sebagai sumber data. Dalam penelitian ini dijadikan sampel berjumlah 50 orang.

Analisis kepuasan konsumen digunakan analisis data secara deskriptif berpedoman pada skala likert. Data yang ingin diperoleh yakni dengan cara memberi angket kepada para konsumen rengginang UD. Sarwani Desa Gelung Kabupaten Situbondo dengan pemberian nilai menggunakan skala likert. Skala Likert digunakan untuk mengukur tingkat kepuasan konsumen terhadap produk rengginang UD. Sarwani. Sementara untuk menjelaskan faktor yang mempengaruhi kepuasan konsumen digunakan analisis regresi linier berganda. Rumus persamaan regresi linier berganda adalah (Djarwanto dan Subagyo, 2005) :

$$
Y=a+b_{1} x_{1}+b_{2} x_{2}+b_{3} x_{3}+b_{4} x_{4}+b_{5} x_{5} . e
$$

Keterangan:

$\alpha$ : Konstanta.

$\mathrm{Y}$ : Kepuasan konsumen.

$\mathrm{X}_{1}$ : Kualitas produk.

$\mathrm{X}_{2}$ : Harga.

$\mathrm{X}_{3}$ : Service quality.

$\mathrm{X}_{4}$ : Emotional factor.

$\mathrm{X}_{5}$ : Biaya.

b1: Koefisien regresi variabel kualitas produk.

$b 2$ : Koefisien regresi variabel harga.

$b 3$ : Koefisien regresi variabel service quality.

$b 4$ : Koefisien regresi variabel emotional factor.

$b 5$ : Koefisien regresi variabel biaya.

$e$ : Toleransi ketidakaktifan/epsilon.

Pengujian secara simultan dan parsial dilakukan untuk mengetahui pengaruh semua variabel independen yang terdapat di dalam model secara bersama-sama (simultan) terhadap variabel dependen. Uji $\mathrm{F}$ dalam penelitian ini digunakan untuk menguji signifikasi pengaruh faktor kualitas produk, harga, service quality, emotional factor, dan biaya terhadap permintaan secara simultan dan parsial.

\section{HASIL DAN PEMBAHASAN}

\section{Kepuasan Konsumen Terhadap Produk Rengginang}

Untuk menjawab hipotesa pertama untuk mengetahui tingkat kepuasan konsumen digunakan analisis data secara deskriptif berpedoman pada skala likert. Data yang ingin diperoleh yakni dengan cara memberi angket kepada para konsumen rengginang UD. Sarwani Desa Gelung Kabupaten Situbondo dengan pemberian nilai menggunakan skala likert. Pada bagian ini di peroleh data kuisioner melalui penyebaran 50 responden dengan mengajukan dari beberapa item pertanyaan. Pertanyaan tersebut tersusun dengan setiap pertanyaan di beri 5 alternatif jawaban, sangat puas, puas, cukup puas, tidak puas, dan sangat tidak puas. Berikut ini adalah data hasil kuisioner yang tersaji dalam Tabel 1 sebagai berikut : 
Tabel 1. Data Jawaban Responden Kepuasan Konsumen

\begin{tabular}{lcccccccc}
\hline & 1 & 2 & 3 & 4 & 5 & Total skor & indeks \% & kriteria \\
\hline Q1 & 0 & 2 & 21 & 18 & 9 & 184 & 73,6 & Puas \\
Q2 & 0 & 2 & 9 & 31 & 8 & 200 & 80 & Sangat puas \\
Q3 & 0 & 0 & 12 & 26 & 12 & 200 & 80 & Sangat puas \\
\hline Total & & & & & & $\mathbf{5 8 4}$ & $\mathbf{2 3 3 , 6}$ & \\
\hline indeks \% & & & & & $\mathbf{2 3 3 , 6}$ & $\mathbf{7 7 , 9 \%}$ & Puas \\
\hline
\end{tabular}

Sumber: Analisis Data Primer, 2019

Berdasarkan Tabel 1 di atas menunjukkan bahwa data jumlah keseluruhan skor pada setiap kriteria, dimana tingkat kepuasan konsumen berada pada index persentase 77,9 \%. Hal ini menunjukkan bahwa mayoritas konsumen UD. Sarwani di Desa Gelung Kecamatan Panarukan Kabupaten Situbondo menjawab puas. Berdasarkan penilaian interval koefisien likert menurut Sugiyono (2006) yaitu 60,00 \% -79,99\% tergolong dalam kriteria puas.

Konsumen dikatakan puas dapat di ukur dari konsumen telah merekomendasikan produk yang di beli kepada orang lain, konsumen berulang kali membeli produk rengginang dari UD. Sarwani, dan mengatakan hal yang baik setelah membeli. Artinya konsumen merasa bahwa produk olahan rengginang yang diproduksi UD. Sarwani memiliki kualitas yang baik, sesuai yang diharapkan oleh konsumen.

Rizki A. Djanaik, Muhammad (2015) menyatakan bahwa tingkat kepuasan pengguna speedy yang diukur dari kepuasan kualitas layanan internet, atribut harga, atribut layanan pembayaran, dan atribut penanganan gangguan. Pengguna merasa sangat puas menilai bahwa kualitas layanan internet speedy sangat baik, akses kecepatan internet sangat cepat dan untuk atribut harga sangat murah, layanan pembayaran mudah bahkan proses penanganan gangguansangat cepat. Sehingga konsumen tertarik untuk berlangganan pada produk speedy. Dan dihitung menggunakan skala likert mendapatkan tingkat kepuasan sangat puas. Persentase tingkat kepuasan speedy sangat tidak puas $0 \%$, kurang puas $12 \%$, puas $18 \%$, sangat puas $70 \%$.

\section{Faktor-Faktor Yang Mempengaruhi Kepuasan Konsumen}

Untuk menjawab hipotesa yang kedua untuk mengetahui faktor-faktor yang berpengaruh terhadap kepuasan konsumen yaitu menggunakan rumus "Analisis Regresi Linear Berganda". Analisis regresi linear digunakan untuk mengetahui pengaruh positif dan negatifnya pengaruh variable bebas $(\mathrm{X})$ terhadap variable terkait $(\mathrm{Y})$, yaitu faktor kualitas produk $\left(\mathrm{X}_{1}\right)$, harga $\left(\mathrm{X}_{2}\right)$, service quality $\left(\mathrm{X}_{3}\right)$, emotional factor $\left(\mathrm{X}_{4}\right)$, biaya $\left(\mathrm{X}_{5}\right)$ terhadap kepuasan konsumen $(\mathrm{Y})$. Kepuasan konsumen dimana dari sampel yang diperoleh, digunakan analisis linier berganda dengan menggunakan rumus sebagai berikut : 
Tabel 2. Regresi Linier Berganda

Coefficients $^{\mathbf{a}}$

\begin{tabular}{|c|c|c|c|c|c|c|}
\hline \multirow{2}{*}{\multicolumn{2}{|c|}{ Model }} & \multicolumn{2}{|c|}{$\begin{array}{l}\text { Unstandardized } \\
\text { Coefficients }\end{array}$} & \multirow{2}{*}{$\begin{array}{l}\text { Standardized } \\
\text { Coefficients } \\
\text { Beta }\end{array}$} & \multirow[b]{2}{*}{$\mathrm{T}$} & \multirow[b]{2}{*}{ Sig. } \\
\hline & & $\mathrm{B}$ & Std. Error & & & \\
\hline \multirow[t]{9}{*}{1} & (Constant) & 3,105 & 0,098 & & 0,000 & 1,000 \\
\hline & Kualitas Produk( $\left.\mathrm{X}_{1}\right)$ & & & & & \\
\hline & & 0,519 & 0,162 & 0,519 & 2,275 & 0,028 \\
\hline & Harga $\left(\mathrm{X}_{2}\right)$ & 0,300 & 0,132 & 0,300 & 4,027 & 0,000 \\
\hline & Service Quality $\left(\mathrm{X}_{3}\right)$ & & & & & \\
\hline & & 0,549 & 0,477 & 0,549 & 2,750 & 0,036 \\
\hline & Emotional Factor $\left(\mathrm{X}_{4}\right)$ & & & & & \\
\hline & & 0,406 & 0,398 & 0,406 & 3,000 & 0,024 \\
\hline & Biaya $\left(\mathrm{X}_{5}\right)$ & 0,556 & 0,271 & 0,556 & 3,077 & 0,027 \\
\hline
\end{tabular}

a. Dependent Variable: Kepuasan Konsumen

Berdasarkan Tabel 2 di atas dapat diperoleh persamaan regresi linier berganda sebagai berikut :

$\boldsymbol{Y}=3,105+0,519 \mathbf{X}_{1}+0,300 \mathbf{X}_{2}+0,549 \mathbf{X}_{3}+0,406 \mathbf{X}_{4}+0,556 \mathbf{X}_{5}$

Berdasarkan persamaan regresi linier berganda tersebut menunjukkan arti dan dapat dijelaskan bahwa :

Konstanta $\alpha=3,105$, Merupakan nilai konstanta, dengan demikian nilai konstanta ini menunjukkan besarnya nilai variabel kepuasan konsumen (Y) UD. Sarwani di Desa Gelung Kecamatan Panarukan Kabupaten Situbondo. Artinya setiap peningkatan satu satuan nilai konstanta maka tingkat konsumen meningkat sebesar satu satuan.

Kualitas produk $\left(\mathrm{X}_{1}\right)=0,519$ menunjukkan bahwa setiap peningkatan kualitas produk sebesar satu satuan atau 1\%, maka kepuasan konsumen meningkat $1 \%$ dan tingkat kepuasan konsumen terhadap kualitas produk UD. Sarwani yaitu 51\% dengan asumsi faktor lainnya tetap karena kualitas produk olahan rengginang UD. Sarwani berkualitas, terjamin dan bermutu.

Harga $\left(\mathrm{X}_{2}\right)=0,300$ menunjukkan bahwa setiap peningkatan harga sebesar satu satuan (rupiah), maka kepuasan konsumen meningkat 1 (rupiah) dan tingkat kepuasan konsumen terhadap harga UD. Sarwani yaitu 30\% dengan asumsi faktor lainnya tetap karena harga yang di tetapkan oleh UD. Sarwani sesuai dengan kualitas produk yang ditawarkan.

Service quality $\left(\mathrm{X}_{3}\right)=0,549$ menunjukkan bahwa setiap peningkatan faktor service quality satu satuan atau 1\%, maka kepuasan konsumen meningkat $1 \%$ dan tingkat kepuasan konsumen terhadap service quality UD. Sarwani yaitu 54\% dengan asumsi faktor lainnya tetap karena pelayanan di UD. Sarwani sangat baik terhadap konsumen sehingga konsumen merasa puas.

Emotional factor $\left(\mathrm{X}_{4}\right)=0,406$ menunjukkan bahwa setiap peningkatan emotional factor satu satuan atau 1\%, maka kepuasan konsumen meningkat $1 \%$ dan tingkat kepuasan konsumen terhadap UD. Sarwani yaitu 40\% dengan asumsi faktor lainnya tetap karena emosi dalam mempengaruhi konsumen sangat positif. Sehingga konsumen memberikan emosi timbal balik yang positif terhadap penilaian pelayanan UD. Sarwani.

Biaya $\left(\mathrm{X}_{5}\right)=0,556$ menunjukkan bahwa setiap peningkatan faktor biaya satu satuan atau $1 \%$, maka kepuasan konsumen meningkat $1 \%$ dan tingkat kepuasan konsumen terhadap 
UD. Sarwani yaitu 55\% dengan asumsi faktor lainnya tetap karena konsumen merasa biaya untuk memperoleh produk UD. Sarwani tidak terlalu mahal dan mudah di jangkau

\section{Pengujian Secara Parsial (Uji t)}

Uji t dilakukan untuk menguji koefisien regresi secara parsial dari variabel independentnya. Uji ini dilakukan denga membandingkan $t_{\text {hitung }}$ dengan $t_{\text {tabel }}$ dengan ketentuan sebagai berikut :

1. Apabila $t_{\text {hitung }} \geq t_{\text {tabel }}$ atau $-t_{\text {hitung }} \leq-t_{\text {tabel, }}$ maka Ho ditolak dan Ha diterima, artinya variabel bebas secara parsial berpengaruh signifikan terhadap variabel terikat.

2. Apabila $t_{\text {hitung }}<t_{\text {tabel }}$ atau $-t_{\text {hitung }}>-t_{\text {tabel, }}$, maka Ho di terima dan Ha di tolak, artinya variabel bebas secara parsial tidak berpengaruh signifikan terhadap variabel terikat.

Berdasarkan nilai probabilitas sebagai dasar pengambilan keputusan adalah sebagai berikut:

1. Apabila angka probabilitas signifikansi $>0,05$, maka Ho diterima dan Ha ditolak, artinya variabel bebas secara parsial tidak berpengaruh signifikan terhadap variabel terikat.

2. Apabila angka probabilitas signifikansi $<0,05$, maka Ho ditolak dan Ha diterima, artinya variabel bebas secara parsial berpengaruh signifikan terhadap variabel terikat. Hasil pengujian hipotesis dengan uji t dapat dilihat pada Tabel 5.2 sebagai berikut:

Mencari t tabel : $(\mathrm{df})=\mathrm{n}-\mathrm{k}(\alpha / 2)$

$$
\begin{aligned}
& : 50-6=44 \times \frac{0,05}{2}=0,025 \\
& : 44\left(\mathrm{t}_{\text {tabel }} 2,015\right)
\end{aligned}
$$

\section{Kualitas Produk $\left(\mathrm{X}_{1}\right)$}

Perhitungan statistik di peroleh nilai $t_{\text {hitung }}$ variabel kualitas produk sebesar 2,275 dan nilai $t_{\text {tabel }}$ sebesar 2,015, maka $t_{\text {hitung }} 2,275>t_{\text {tabel }} 2,015$. Yaitu HO ditolak dan Ha diterima. Hal ini berarti variabel kualitas produk mempunyai pengaruh signifikan. Hal ini juga di perkuat dengan nilai signifikan 0,028 $<0,05$ artinya variabel kualitas produksi berpengaruh secara parsial terhadap kepuasan konsumen pada UD. Sarwani di Desa Gelung Kecamatan Panarukan Kabupaten Situbondo. Konsumen melihat bahwa kualitas produk rengginang UD. Sarwani sangat baik, dilihat dari kemasan terdapat label yang bersertifikatkan halal, dan produk terlihat segar tidak mudah rusak bahkan tahan sampai dengan 1 tahun. Rasanya pun bermacam-macam sehingga konsumen dapat memilih rasa yang diinginkan, dari segi bentuk yang berbentuk lingkaran pipih dan bulat menjadi daya tarik minat konsumen dalam membeli produk rengginang olahan UD. Sarwani.

Hal ini sejalan dengan penelitian Ayushinta, Gita (2013) menyatakan bahwa variabel kualitas pelayanan berpengaruh positif terhadap kepuasan konsumen. Kualitas produk yang meningkat maka kepuasan pelanggan juga meningkat. Kualitas produk cukup dinilai baik oleh konsumen. Hal ini terlihat dari pengaruh langsung yang diberikan kualitas produk terhadap kepuasan konsumen sudah termasuk kuat. Kualitas produk dapat digunakan sebagai salah satu cara untuk meningkatkan kepuasan konsumen. Kepuasan konsumen merupakan suatu evaluasi pasca pembelian yaitu dengan membandingkan harapan konsumen dengan kenyataan yang diterimanya.

2. Harga $\left(\mathrm{X}_{2}\right)$

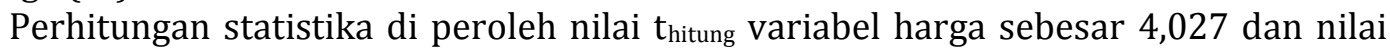
$t_{\text {tabel }}$ sebesar 2,015, maka $t_{\text {hitung }} 4,027>t_{\text {tabel }} 2,015$. Yaitu H0 ditolak dan Ha diterima. Hal ini berarti variabel harga mempunyai pengaruh signifikan. Hal ini juga di perkuat dengan nilai signifikan $0,000<0,05$ artinya variabel kualitas produksi berpengaruh secara parsial terhadap kepuasan konsumen pada UD. Sarwani di Desa Gelung Kecamatan Panarukan Kabupaten Situbondo. Harga menunjukkan variabel paling dominan dibandingkan dengan 
variabel kualitas produk $\left(\mathrm{X}_{1}\right)$, service quality $\left(\mathrm{X}_{3}\right)$, emotional factor $\left(\mathrm{X}_{4}\right)$, biaya $\left(\mathrm{X}_{5}\right)$. Konsumen merasa puas karena harga yang di tetapkan oleh UD. Sarwani cukup murah sesuai dengan variasi rasa. Harga tersebut merupakan perhitungan dari semua biaya yang di keluarkan. Konsumen menilai bahwa harga tersebut sudah sangat sesuai dengan kualitas produk yang di produksi UD. Sarwani. Bila dibandingkan dengan harga produk lain yang sejenis harganya sesuai dengan standart pasar. Konsumen tidak merasa keberatan umtuk membeli produk dari UD. Sarwani yang terkenal murah dengan kualitas yang baik. Hal ini berarti variabel harga mempunyai pengaruh signifikan.

Hasil penelitian ini sejalan dengan penelitian yang dilakukan oleh Prasetio, Ari (2012) menyatakan bahwa harga berpengaruh positif dan signifikan terhadap kepuasan pelanggan PT. TIKI Cabang Semarang. Dengan demikian, hasil penelitian ini mendukung hasil penelitian sebelumnya. Harga merupakan sejumlah nilai yang dibebankan atas suatu produk atau jasa yang diberikan oleh konsumen untuk memperoleh keuntungan dari menggunakan produk atau jasa. Murah atau mahalnya harga suatu produk atau jasa sifatnya relatif. Harga yang terlalu tinggi tanpa diimbangi dengan kualitas yang baik maka dapat menimbulkan kekecewaan konsumen. Dengan demikian, dalam menetapkan harga, pemilik usaha harus menyesuaikan harga dengan kualitas produk atau jasa yang ditawarkan. Selain itu, pemilik usaha juga perlu membandingkan harga yang ditetapkan dengan harga produk atau jasa serupa yang diproduksi atau ditawarkan oleh pesaing. Hal ini dimaksudkan agar harga yang ditentukan oleh perusahaan tersebut tidak terlalu tinggi atau sebaliknya.

\section{Service Quality $\left(\mathrm{X}_{3}\right)$}

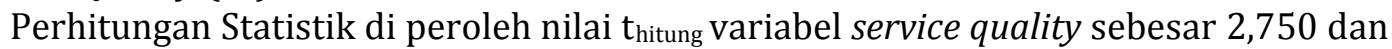
nilai $t_{\text {tabel }}$ sebesar 2,015, maka $t_{\text {hitung }} 2,750>t_{\text {tabel }} 2,015$. Yaitu H0 ditolak dan Ha diterima. Hal ini berarti variabel service quality mempunyai pengaruh signifikan. Hal ini juga di perkuat dengan nilai signifikan 0,036 < 0,05 artinya variabel Service Quality berpengaruh secara parsial terhadap kepuasan konsumen pada UD. Sarwani di Desa Gelung Kecamatan Panarukan Kabupaten Situbondo. Konsumen melihat bahwa pelayanan di UD. Sarwani sangat baik, karena melihat bukti langsung saat konsumen datang membeli menilai fasilitas, peralatan, penampilan staff yang digunakan cukup memadai. Keandalan dalam melayani konsumen mampu memberikan layanan yang di janjikan secara akurat, daya tanggap dalam melayani konsumen, membantu dan memberikan layananan yang cepat sehingga konsumen merasa puas saat membeli produk dari UD. Sarwani.

Hasil penelitian ini sejalan dengan konsep dari penelitian yang dilakukan Parasuraman dan Leonard L.Berry (1998) menyatakan bahwa kualitas pelayanan dikatakan memuaskan jika layanan yang dirasakan sama atau melebihi kualitas layanan yang diharapkan. Pelayanan yang seperti inilah yang dipersepsikan sebagai pelayanan berkualitas dan ideal. Harapan konsumen tersebut tercermin pada dimensi kualitas pelayanan seperti tangibles, responsiveness, waktu, dan kecepatan dalam pengiriman barang menjadi nilai penting yang diharapkan oleh para konsumen. Oleh karena itu, kualitas pelayanan harus menjadi fokus utama perhatian perusahaan karena dapat menciptakan kepuasan konsumen.

\section{Emotional Factor $\left(\mathrm{X}_{4}\right)$}

Perhitungan statistika di peroleh nilai thitung variabel Emotional Factor sebesar 3,000 dan nilai $t_{\text {tabel }}$ sebesar 2,015, maka $t_{\text {hitung }} 3,000>t_{\text {tabel }} 2,015$. Yaitu H0 ditolak dan Ha diterima. Hal ini berarti variabel emotional factor mempunyai pengaruh signifikan. Hal ini juga di perkuat dengan nilai signifikan $0,024<0,05$ artinya variabel emotional factor berpengaruh secara parsial terhadap kepuasan konsumen pada UD. Sarwani di Desa Gelung Kecamatan Panarukan Kabupaten Situbondo. Konsumen menilai bahwa kenyamanan saat membeli produk yang ada di UD. Sarwani yaitu dapat memilih sendiri produk yang di beli, disambut dengan baik ketika datang langsung ke tempat produksi, 
tempat produksi aman, dan dekat dengan tempat wisata pantai. Sehingga menjadi daya tarik sendiri bagi konsumen untuk membeli produk dari UD. Sarwani.

Hasil penelitian serupa juga ditemukan oleh Kusuma dan Suwitho (2015) juga mendapatkan bahwa variabel emosional berpengaruh signifikan terhadap kepuasan pelanggan. Pemasaran emosional berkaitan dengan perasaan atau emosi seseorang. Pembelian yang didasari motivasi emosional didasari pada alasan yang subjektif atau pribadi. Pemasaran emosional seperti perasaan aman yang dirasakan pelanggan membuat pelanggan merasa puas.

5. Biaya $\left(\mathrm{X}_{5}\right)$

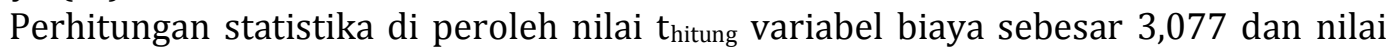
$t_{\text {tabel }}$ sebesar 2,015, maka $t_{\text {hitung }} 3,077>t_{\text {tabel }} 2,015$. Yaitu H0 ditolak dan Ha diterima. Hal ini berarti variabel biaya mempunyai pengaruh signifikan. Hal ini juga di perkuat dengan nilai signifikan $0,027<0,05$ artinya variabel biaya berpengaruh secara parsial terhadap kepuasan konsumen pada UD. Sarwani di Desa Gelung Kecamatan Panarukan Kabupaten Situbondo. Konsumen merasa puas untuk biaya yang di keluarkan untuk mendapatkan produk rengginang UD. Sarwani yang dibilang cukup murah karena lokasinya yang mudah di jangkau, kalaupun ada pemesanan dari luar kota biaya pengiriman murah, dikirim menggunakan jasa pengiriman dengan prosesnya yang sangat cepat. Sehingga konsumen tidak keberatan untuk melakukan pemesanan membeli produk dari UD. Sarwani. Hal ini berarti variabel biaya mempunyai pengaruh signifikan. Hal ini sejalan dengan penelitian Irawan (2004) menyatakan bahwa variabel biaya berpengaruh signifikan terhadap kepuasan konsumen. Semakin mudah konsumen memperoleh hal yang diinginkannya maka semakin tinggi kepuasan yang dirasakannya.

\section{Uji Simultan (Uji F)}

Uji simultan atau uji $\mathrm{F}$ merupakan uji secara bersama-sama untuk menguji pengaruh signifikan variabel kepuasan konsumen terhadap UD. Sarwani di Desa Gelung Kecamatan Panarukan Kabupaten Situbondo.

Tabel 3. Hasil Uji F

ANOVAa

\begin{tabular}{|ll|l|l|l|l|l|}
\hline \multicolumn{2}{|l|}{ Model } & $\begin{array}{l}\text { Sum } \\
\text { Squares }\end{array}$ & Df & Mean Square & F & Sig. \\
\hline 1 & Regression & 27,732 & 5 & 5,546 & 11,474 & $0,000^{\mathrm{b}}$ \\
& Residual & 21,268 & 44 & 0,483 & & \\
& Total & 49,000 & 49 & & & \\
\hline
\end{tabular}

a. Dependent Variable: Kepuasan Konsumen

b. Predictors: (Constant), Biaya, Kualitas Produksi, Harga, Emotional Factor, Service Quality

$$
\begin{aligned}
\text { Mencari F tabel : } & \mathrm{df}_{1}=\mathrm{K}-1 \\
& : \mathrm{df}_{1}=6-1=5 \\
& : \mathrm{df}_{2}=\mathrm{n}-\mathrm{K} \\
& : 50-6=44\left(\mathrm{~F}_{\text {tabel }} 2,430\right)
\end{aligned}
$$

Berdasarkan Tabel 3 di atas pengujian statistik dengan menggunakan metode uji $\mathrm{F}$, dimana nilai $F_{\text {hitung }} 11,474>F_{\text {tabel }} 2,430$ dengan tingkat signifikan yang diperoleh $0,000<$ 0,05, maka dapat disimpulkan bahwa terdapat pengaruh kepuasan konsumen terhadap UD. Sarwani di Desa Gelung Kecamatan Panarukan Kabupaten Situbondo. Hasil penelitian ini relevan dengan penelitian menurut Wahyuno (2013) menyatakan bahwa kualitas 
pelayanan dan harga berpengaruh positif dan signifikan secara parsial dan simultan terhadap kepuasan konsumen di Hotel Anugerah Glagah Indah.

\section{KESIMPULAN DAN SARAN \\ Kesimpulan}

Berdasarkan dari hasil penelitian yang telah di lakukan dan telah diuraikan sebelummya, maka dapat di tarik kesimpulan dari keseluruhan hasil penelitian yaitu:

1. Analisa tingkat kepuasan konsumen pada produk olahan rengginang UD. Sarwani di Desa Gelung Kecamatan Panarukan Kabupaten Situbondo berada pada index persentase $77,9 \%$. Hal ini menunjukkan bahwa konsumen puas terhadap produk olahan UD. Sarwani.

2. Melalui pengujian secara parsial dan secara simultan bahwa faktor kualitas produk, harga, service quality, emotional factor dan biaya dimana nilai $F_{\text {hitung }} 11,474>F_{\text {tabel }}$ 2,430 dengan tingkat signifikan 0,000 $<0,05$ maka dapat disimpulkan bahwa terdapat pengaruh kepuasan konsumen terhadap UD. Sarwani di Desa Gelung Kecamatan Panarukan Kabupaten Situbondo.

\section{Saran}

Berdasarkan semua hasil penelitian yang dilakukan, maka saran dari peneliti adalah:

1. Untuk menatik minat konsumen selama proses keputusan pembelian dan akhirnya dapat mengambil keputusan untuk membeli produk tersebut, pemilik agroindustri UD.Sarwani hrus menetapkan harga yang terjangkau, menetapkan harga sesuai dengan kualitas produknya agar konsumen tetap merasa puas .

2. Produsen harus lebih mengembangkan usahanyanya agar produknya dapat dikenal oleh masyarakat khususnya dalam kota maupun luar kota. Semakin baik kualitas yang di tawarkan maka semakin banyak minat konsumen untuk membeli.

\section{REFERENSI}

Djarwanto, PS dan Pangestu, Subagyo. 2005. Statistik Induktif, Edisi keempat. Yogyakarta.

Ghozali, Imam. 2005. Aplikasi Analisis Multivariate dengan Program SPSS. Semarang: Badan Penerbit Universitas Diponegoro.

Rachman, B. dan Sumedi. 2002. Kajian Efisiensi Manajemen dalam Pengelolaan Agroindustri dalam Analisis Kebijakan: Paradigma Pembangunan dan Kebijaksanaan Pengembangan Agroindustri. Monograph Series No.21. Pusat Penelitian Sosial Ekonomi Pertanian Bogor.

Sugiyono. 2006. Metode Penelitian Kuantitatif, Kualitatif dan R \& D.Bandung: Alfabeta.

Sugiyono. 2008. Metode Penelitian Kuantitatif Kualitatif dan R\&D. Bandung Alfabeta.

Sugiyono. 2008. Metode Penelitian Bisnis. Bandung. Alfabeta.

Sugiyono. 2011. Metode Penelitian Kuantitatif, Kualitatif dan R\&D. Bandung: Afabeta.

Sugiyono. (2014). Metode Penelitian Pendidikan Pendekatan Kuantitatif, Kualitatif, dan R\&D. Bandung: Alfabeta 